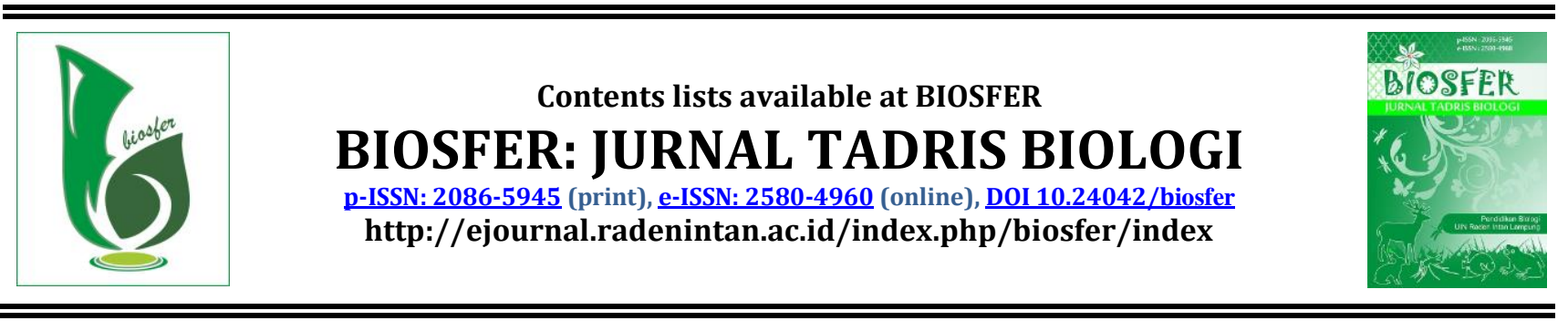

\title{
The Allelopathic Effects Characteristics of Fresh Jatropha (Jatropha curcas L.) Leaves Extract on the Germination and Growth of Bok Choy (Brassica rapa L.) Sprouts
}

\author{
Dian Putri Sani ${ }^{1 *}$, Tundjung Tripeni Handayani ${ }^{2}$, Zulkifli Zulkifli ${ }^{3}$, Martha Lulus Lande ${ }^{4}$ \\ 1, 2, 3, 4 Universitas Lampung, Indonesia
}

\begin{abstract}
ARTICLE INFO
Article History

Received : April 15th 2020

Accepted : May $18^{\text {th }}, 2020$

Published : June $29^{\text {th }}, 2020$

Keywords:

Bok Choy;

Brassica rapa L.;

Jatropha;

Jatropha curcas L.;

Allelopathy

*Correspondence Address: dianputrisani123@gmail.com

ABSTRACT

The purpose of this study was to determine the concentration of Jatropha (Jatropha curcas L.) leaves extract on the germination and growth of Bok Choy (Brassica rapa L.). This study employed the completely randomized design with Jatropha (Jatropha curcas L.) leaves extract as the primary factor within 5 levels of concentration, namely $0 \% \mathrm{v} / \mathrm{v}, 5 \% \mathrm{v} / \mathrm{v}, 10 \% \mathrm{v} / \mathrm{v}, 15 \% \mathrm{v} / \mathrm{v}$, and $20 \% \mathrm{v} / \mathrm{v}$. The treatments were repeated 5 times. The variables measured in this study were root length, fresh and dry weight (aerial part and root), the length of aerial part, relative water content, and the total count of chlorophyll a,b. The homogeneity of the data was tested using the Levene statistics. The results showed that allelopathy of the Jatropha caused a stimulatory effect on the fresh weight and the dry weight of the sprouts with a maximum concentration of $10 \% \mathrm{v} / \mathrm{V}$. The fresh weight increased from 38.22 to 49.16 or $22.25 \%$ while the dry weight increased from 3.40 to 4.42 or $23.07 \%$.
\end{abstract}

\section{Karakteristik Efek Alelopati Ekstrak Air Daun Segar Jarak Pagar (Jatropha Curcas L.) Terhadap Perkecambahan Dan Pertumbuhan Kecambah Sawi Pakcoy (Brasicca Rapa L.)}

\footnotetext{
Abstrak: Tujuan dari penelitian ini adalah untuk mengetahui konsentrasi ekstrak air daun jarak pagar (Jatropha curcas L.) terhadap perkecambahan dan pertumbuhan kecambah sawi pakcoy (Brassica rapa L.). Penelitian ini menggunakan metode RAL (Rancangan Acak Lengkap) dengan faktor utamanya adalah ekstrak air daun jarak pagar (Jatropha curcas L.) dengan 5 taraf konsentrasi yaitu $0 \% \mathrm{v} / \mathrm{v}, 5 \% \mathrm{v} / \mathrm{v}, 10 \% \mathrm{v} / \mathrm{v}, 15 \% \mathrm{v} / \mathrm{v}$, dan $20 \% \mathrm{v} / \mathrm{v}$ sebagai perlakuan dan setiap perlakuan diulang sebanyak $5 \mathrm{x}$. Variabel yang diukur dalam penelitian ini panjang akar, berat segar dan berat kering (aerial part dan akar), panjang aerial part, kadar air relative, dan kandungan klorofil a,b serta total kecambah. Data yang diperoleh di homogenitas dengan uji Levene. Hasil penelitian menunjukkan bahwa alelopati dari jarak pagar menyebabkan efek stimulasi terhadap berat segar kecambah dan berat kering kecambah dengan konsentrasi maksimum 10\% v/v. Berat segar mengalami peningkatan
} 
dari 38,22 menjadi 49,16 atau sebesar 22,25\% sedangkan berat kering mengalami peningkatan dari 3,40 menjadi 4,42 atau sebesar $23,07 \%$.

\section{INTRODUCTION}

Jatropha (Jatropha curcas L.) is an annual plant belonging to the Euphorbiaceae. It has various utilities of seeds extract oil and biodiesel production (Ir Sukaria Sinulingga \& Tambunan, t.t.; Muthmainnah dkk., 2018; Prabowo, 2019). The oil extracted from the seeds (Kojong dkk., 2013; Risyad dkk., 2016) has toxic compounds which are curcumin and phorbol ester 12-de-oxy-16-hydroxiforbol (Sudaryono, 2010).

However, Jatropha plant can be consumed as table salt, and as substitutes for fuel, dyes, wounds healer, dysentery and jaundice, as well as flower extract can be used as medicine (Sarimole dkk., 2014; Setyaningsih dkk., 2013; Ulung \& Studi, 2014). Jatropha has very short and broad rods, making them almost invisible. This stem functions as a leaf shaper and support growth or is often called heavy feeders.

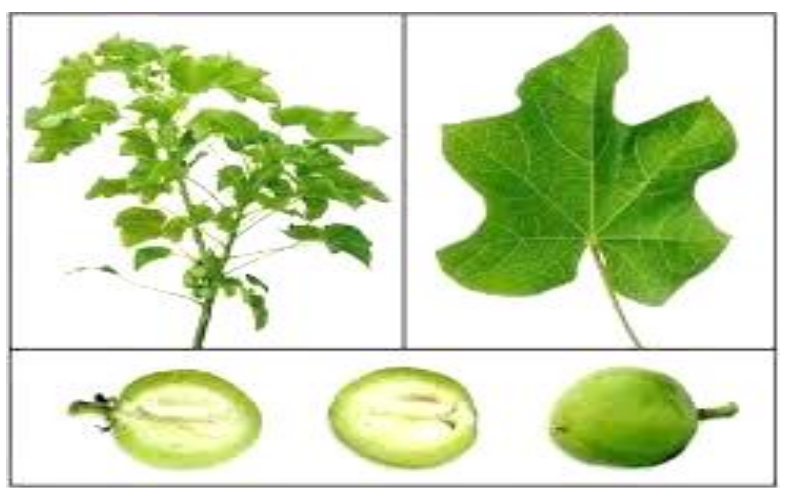

Figure 1. Jatropha Plant

Research on Jatropha had been done by (Sanderson dkk., 2013) on leaf extract. (Rejila \& Vijayakumar, 2011) showed stimulatory effects and (Siadi, 2012) states that Jatropha plants can be utilized as biopesticides.

Bok Choy sprouts, which originated from China, can grow well in the highlands and the lowlands (Firmansyah dkk., 2009). Bok Choy has smooth leaves, no hair, and no head shape. Its stems are wide and sturdy. The spines of the leaves and the leaves are similar to green mustard, but the leaves are thicker. Bok Choy also contains many nutrients including protein, vegetable fat, carbohydrates, fiber, $\mathrm{Ca}, \mathrm{Mg}$, sodium, vitamin A, and Vitamin C (Efriyadi, 2018; Perwitasari dkk., 2012; Tiya dkk., 2019). Jatropha leaves water extract showed inhibitory effects on seed germination, shoot length, and root length of green chili (Capsicum anum L.) and Bok Choy (Brassica rapa L.) (Rejila \& Vijayakumar, 2011). Bok Choy (Brassica rapa L.) is a type of vegetables belonging to the Brassicaceae (Kasmiyati dkk., 2018; Wiryono \& Nurliana, 2019). The Bok Choy originates from China and was introduced to Japan. It is in the same family as Chinese vegetables (Harahap \& Sari, 2019). Bok Choy requires more nitrogen for its growth is often called heavy feeders (Barokah, R., Sumarsono, S., \& Darmawati, A., 2017).

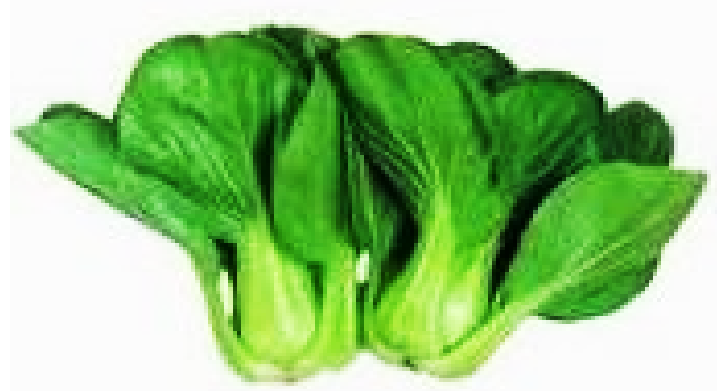

Figure 2. Bok Choy

The high beta-carotene content in Bok Choy can prevent cataracts (Tiya dkk., 2019; Wenno, S. J., \& Sinay, H. 2019). Besides containing high beta-carotene, Bok Choy also contains many nutrients including protein, vegetable fat, carbohydrates, fiber, $\mathrm{Ca}$, $\mathrm{Mg}$, sodium, vitamin A, and Vitamin C (Efriyadi, 2018; Perwitasari dkk., 2012; Tiya dkk., 2019). 
This study was done because there has been no previous study that examines the characteristics of Jatropha extracts on Bok Choy.

\section{METHOD}

This research was conducted in January 2019 at the Botany I Laboratory, Department of Biology, Faculty of Mathematics and Natural Sciences, University of Lampung. The tools used in this study were beaker glass, Erlenmeyer flask, measuring cups, trays, test tubes, and racks, pipette drop, plastic cups, labels, blenders, rubber bands, UV spectrophotometers, digital scales, rulers, ovens, funnels, scissors, knife, and centrifuge.

The materials used in this study included the seeds of Bok Choy of Nauli F1 varieties produced by PT. East-West Indonesia, 96\% alcohol, tissue, distilled water, Jatropha leaves taken from Pringsewu area, and Whatman filter paper No. 1.

The experiment was carried by employing the Completely Randomized Design (CRD) with Jatropha leaves water extract as the main factor consisting of 5 levels of concentration: $0 \% \mathrm{v} / \mathrm{v}, 5 \% \mathrm{v} / \mathrm{v}$, $10 \% \mathrm{v} / \mathrm{v}, 15 \% \mathrm{v} / \mathrm{v}, 20 \% \mathrm{v} / \mathrm{v}$ as the treatments. Each treatment was replicated 5 times. The dependent variable in this study was the root length, the length of the aerial parts, dry weight, fresh weight, dry weight of the aerial part, fresh weight of the aerial part, relative water content, and the total count of chlorophyll a,b. The independent variable in this study was the concentration of Jatropha leaves water extract. The parameter of this study was the mean $(\mu)$ variable of germination growth.

The Jatropha leaves water extract stock solution was made by smoothing 100 grams of Jatropha leaves by using a blender and then added $500 \mathrm{ml}$ of water. After that, it was filtered into beaker glass which produced $20 \% \mathrm{v} / \mathrm{v}$. The Bok Choy seeds were selected to obtain good seeds by soaking them in water for 24 hours. The seeds were germinated using a tray that had been coated with distilled water-soaked tissue paper. The trays consisted of 5 cups and each cup was given 32 seeds. The selected seeds were then sprayed with distilled water for 7 days to germinate.

The plastic cups used as a place seeds growth were washed first. 25 plastic cups were labeled with treatment and repetition notation. Each germinated seed contained in the trays was then transferred to a plastic cup to be observed for 7 days. On the second day, the germinated seed was treated by giving $10 \mathrm{ml}$ of Jatropha fresh leaves water extract with a concentration of $5 \%, 10 \%, 15 \%$, and $20 \%$. The observation on the sprouts was carried out after 7 days of planting. The observed variables were the root length, the length of the aerial parts, dry weight, fresh weight, dry weight of the aerial part, fresh weight of the aerial part, relative water content, and the total count of chlorophyll a,b.

By using a UV spectrophotometer at wavelengths of $648 \mathrm{~nm}$ and $664 \mathrm{~nm}$, the absorbance of the chlorophyll extract was measured. Levene test used to determine the homogeneity of the data. After that, a variety of analysis was carried out at the $5 \%$ significance level. If there were differences between treatments, then a further test should have been performed with the Tukey method. The relationship between the concentrations of Jatropha leaves water extract with the germination growth was determined based on linear regression.

\section{RESULTS AND DISCUSSION}

The germination growth was evaluated based on the changes in the length of root and the length of aerial parts and the fresh and dry weight of the sprouts. 
Biosfer: Jurnal Tadris Biologi, 11 (1) (2020) 26 - 34

Dian Putri Sani, Tundjung Tripeni Handayani, Zulkifli, Martha Lulus Lande

Table 1. The Effect of Jatropha Fresh Leaves Water Extract on the Growth of Bok Choy

\begin{tabular}{|c|c|c|c|c|}
\hline $\begin{array}{c}\text { Extract } \\
\text { Concentration } \\
(\% \mathrm{v} / \mathrm{v})\end{array}$ & $\begin{array}{l}\text { The Length of the } \\
\text { Aerial Part }(\mathrm{cm})\end{array}$ & $\begin{array}{l}\text { The Length of } \\
\text { Root }(\mathrm{cm})\end{array}$ & $\begin{array}{l}\text { Fresh Weight } \\
\text { (mg) }\end{array}$ & $\begin{array}{l}\text { Dey Weight } \\
\text { (mg) }\end{array}$ \\
\hline Control & $3,32 \pm 0,15$ & $3,3 \pm 0,41$ & $38,22 \pm 2,74 \mathrm{a}$ & $3,40 \pm 0,27$ a \\
\hline 5 & $3,58 \pm 0,43$ & $3,46 \pm 0,37$ & $41,92 \pm 1,97 \mathrm{a}$ & $3,42 \pm 0,09 \mathrm{a}$ \\
\hline 10 & $3,58 \pm 0,27$ & $3,8 \pm 0,94$ & $49,16 \pm 3,60 a b$ & $4,42 \pm 0,20^{b}$ \\
\hline 15 & $3,84 \pm 0,23$ & $4,0 \pm 0,57$ & $38,64 \pm 1,65^{a}$ & $3,40 \pm 0,23$ a \\
\hline 20 & $3,36 \pm 0,17$ & $3,54 \pm 0,20$ & $32,96 \pm 3,75$ ac & $3,12 \pm 0,20$ a \\
\hline
\end{tabular}

The Tukey test at a 5\% significance level showed that the control's fresh weight was not significantly different from the treatments. Then the fresh weight of $10 \%$ treatment was significantly different from the fresh weight of $20 \%$ treatment. The control's dry weight was significantly different from the dry weight of $10 \%$ treatment.

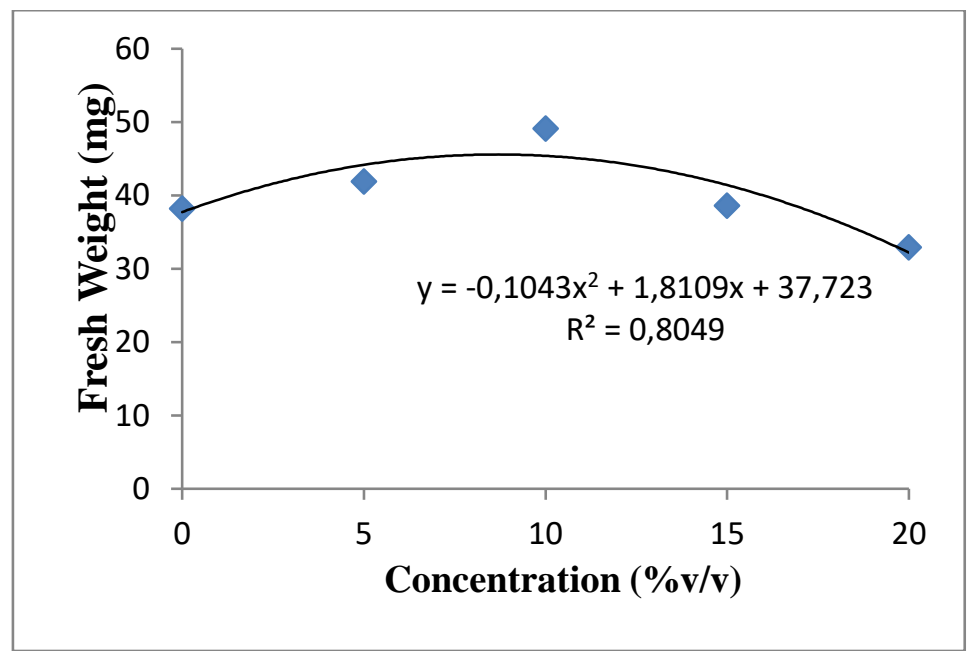

Figure 3. The Relationship between the Concentration of Jatropha Fresh Leaves Water Extract and Fresh Weight of Sprouts (mg)

The equation of $\mathrm{y}=-0.104 \mathrm{x}^{2}+$ $1.810 \mathrm{x}+37.72$ with the coefficient of determination $\left(\mathrm{R}^{2}\right)$ of 0.804 and the correlation coefficient $(\mathrm{r})$ of 0.90 showed the relationship strong between the extract and the fresh weight. The optimum concentration of Jatropha fresh leaves water extract can stimulate fresh weight by $8.7 \%$ with a maximum fresh weight of 45.55 mg. 
Biosfer: Jurnal Tadris Biologi, 11 (1) (2020) 26 - 34

Dian Putri Sani, Tundjung Tripeni Handayani, Zulkifli, Martha Lulus Lande

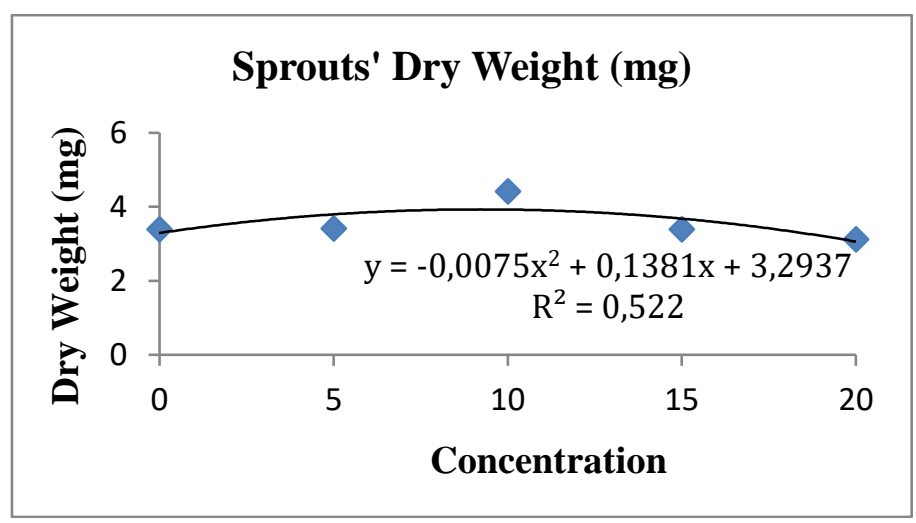

Figure4. The Relationship between the Concentration of Jatropha Fresh Leaves Water Extract and Sprouts' Dry Weight (mg)

The equation of $y=-0.007 x^{2}+0.138 x$ +3.293 with the coefficient of determination $\left(R^{2}\right)$ of 0.522 and the correlation coefficient ( $\mathrm{r}$ ) of 0.72 showed a strong relationship between the extract and the dry weight. The optimum concentration of Jatropha extract can stimulate dry weight by $9.2 \%$ with a maximum dry weight of 3.93 mg.
The Levene test at 5\% on the relative water content level showed that the sample was homogeneous (attachment $2 \mathrm{p}$-value > $0.05)$. The analysis of variance at a $5 \%$ significance level did not affect the relative water content of Bok Choy sprouts.

Table 2. The Relationship between the Concentration of Jatropha Fresh Leaves Water Extract and the Relative Water Content of Bok Choy Sprouts

\begin{tabular}{cc}
\hline Extract Concentration $(\% \mathrm{v} / \mathrm{v})$ & Relative water content $(\%)$ \\
\hline Control & $91.1 \pm 0.23$ \\
5 & $91.82 \pm 0.24$ \\
10 & $90.9 \pm 0.56$ \\
15 & $91.22 \pm 0.44$ \\
20 & $90.38 \pm 0.64$ \\
\hline
\end{tabular}

Based on the table, it can be stated that there was no significant increase in relative water content levels when given a significantly increased concentration. However, each concentration produced different quantities of water.

Table 3. The Relationship between the Concentration of Jatropha Fresh Leaves Water Extract and the Total Count of Chlorophyll a, b

\begin{tabular}{cccc}
$\begin{array}{c}\text { Extract } \\
\text { Concentration }(\%)\end{array}$ & $\begin{array}{c}\text { Chlorophyll Content } \\
\mathrm{a}\end{array}$ & $\begin{array}{c}\text { Chlorophyll Content } \\
\mathrm{b}\end{array}$ & $\begin{array}{c}\text { Total Chlorophyll } \\
\text { Content }\end{array}$ \\
\hline Control & $0,59 \pm 0,02^{\mathrm{a}}$ & $0,85 \pm 0,01^{\mathrm{a}}$ & $1,44 \pm 0,04^{\mathrm{a}}$ \\
5 & $0,67 \pm 0,04^{\mathrm{a}}$ & $0,90 \pm 0,02^{\mathrm{a}}$ & $1,57 \pm 0,05^{\mathrm{a}}$ \\
10 & $0,70 \pm 0,01^{\mathrm{ab}}$ & $0,91 \pm 0,01^{\mathrm{ab}}$ & $1,61 \pm 0,03^{\mathrm{ab}}$ \\
15 & $0,50 \pm 0,12^{\mathrm{a}}$ & $0,70 \pm 0,17^{\mathrm{a}}$ & $1,19 \pm 0,30^{\mathrm{a}}$ \\
20 & $0,33 \pm 0,14^{\mathrm{ac}}$ & $0,51 \pm 0,21^{\mathrm{ac}}$ & $0,84 \pm 0,34^{\mathrm{ac}}$ \\
\hline
\end{tabular}

$\operatorname{HSD}[0.5]=0.36 \mathrm{HSD}[0.5]=0.36 \mathrm{HSD}[0.5]=0.36$ 
Based on Table 3, the chlorophyll content on each concentration changed. The chlorophyll content was not only increased but some were stated to decrease. Therefore, the extract concentration affected certain chlorophyll content.

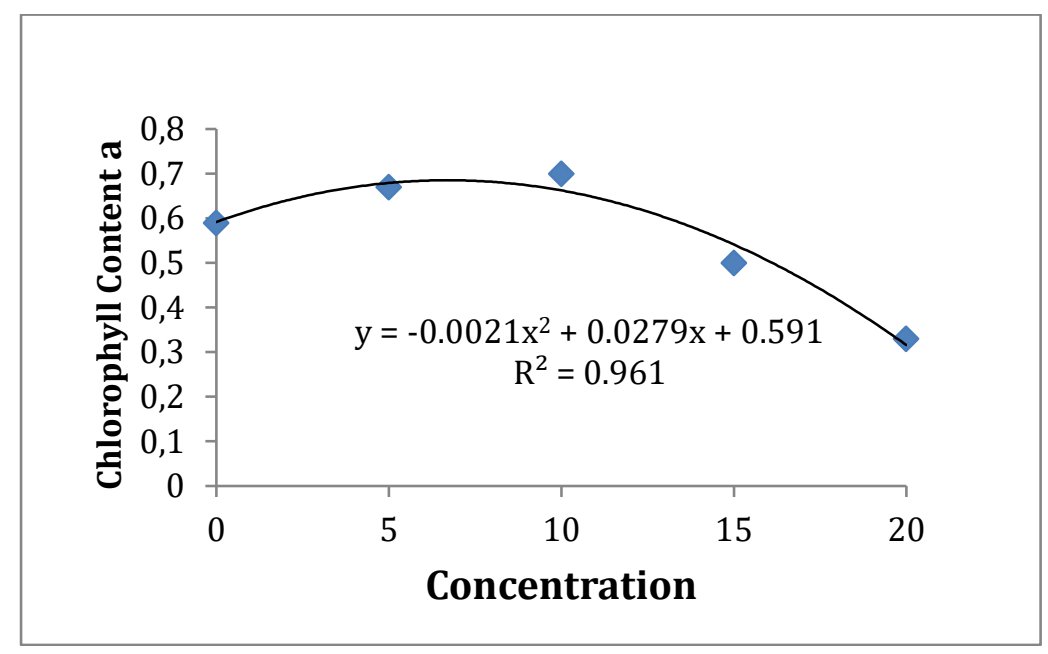

Figure5. The Relationship between the Concentration of Jatropha Fresh Leaves Water Extract and Chlorophyll Content a

The equation of $y=-0.0021 x 2+$ $0.0279 x+0.591$ with the coefficient of determination $\left(\mathrm{R}^{2}\right)$ of 0.961 and the correlation coefficient ( $\mathrm{r}$ ) of 0.98 showed a strong relationship between the extract and the dry weight. The optimum concentration of the extract can stimulate chlorophyll-a levels by $6.6 \%$ with maximum chlorophyll-a of $0.68 \mathrm{mg}$.

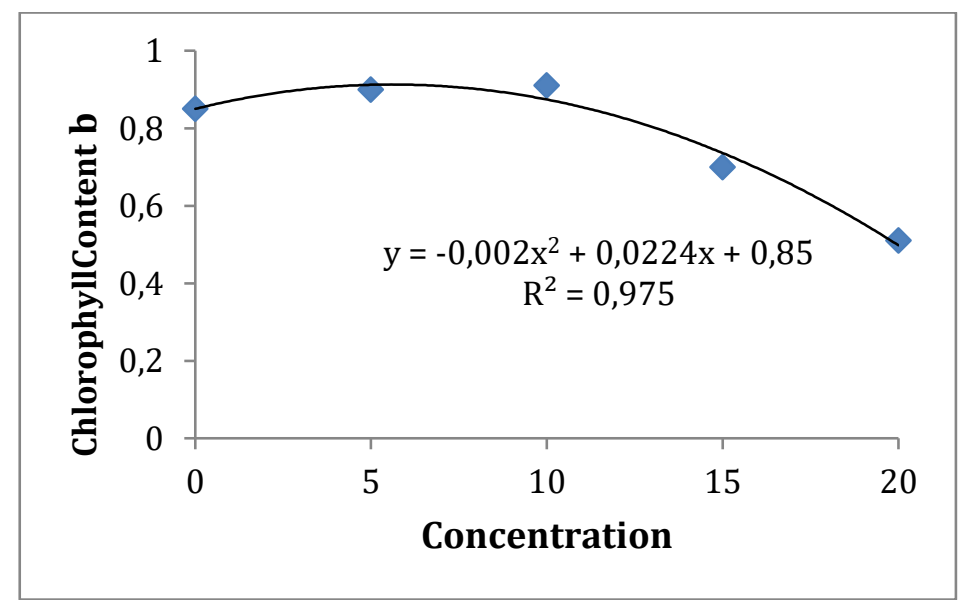

Figure 6. The Relationship between the Concentration of Jatropha Fresh Leaves Water Extract and Chlorophyll Content b

The equation $y=-0.002 x^{2}+0.022 x+$ 0.85 with the coefficient of determination $\left(\mathrm{R}^{2}\right)$ of 0.975 and the correlation coefficient (r) of 0.99 showed the strong relationship between the extract and the dry weight. The optimum concentration of the extract can stimulate chlorophyll b level by $5.6 \%$ with maximum chlorophyll b of $0.91 \mathrm{mg}$.

The experiment (aqueous extract bioassay) was carried out under laboratory conditions to determine the potential residues of various concentrations of aqueous extract of Jatropha fresh leaves 
extract toward the germination growth of Bok Choy. Table 1 shows that the allelopathic action of Jatropha curcas has a stimulatory effect on the fresh weight and the dry weight of the sprouts with a maximum concentration of $10 \% \mathrm{v} / \mathrm{v}$. Fresh weight increased from 38.22 to 49.16 or $22.25 \%$ while the dry weight increased from 3.40 to 4.42 or $23.07 \%$.

Based on the results of this study, at the concentration of $15 \%$ and $20 \%$, the growth of aerial parts began to decline. There were no allelopathy effects of Jatropha leaves water extract on the length of aerial and the length of the root. The results showed that Jatropha leaves water extract at a concentration of $20 \%$ tended to reduce chlorophyll content $\mathrm{a}, \mathrm{b}$ and the total numbers of Bok Choy leave. However, there was no effect on relative water content.

The intensity of the allelopathic effect depends on the concentration of the substance contained in the extract. Allelopathic compounds may act synergistically which causes effects that might activate or inhibit the growth of other plants depending on the tested concentration.

Previous research by (Sanderson dkk., 2013) proved that Jatropha leaves extract did not provide an allelopathic effect on lettuce seeds germination, however, a concentration of $15 \%$ significantly inhibited the development of aerial and radicular parts. Meanwhile, (Rejila \& Vijayakumar, 2011) state that Jatropha extract (Jatropha curcas L.) showed a stimulatory effect on seed germination and shoot length in Sesamum indicum $L$. The stimulation effect was directly proportional to the increase in concentration $(5 \%, 10 \%, 15 \%, 20 \%)$. However, this did not occur in root growth where all treatments were inhibited and the control was not inhibited.

\section{CONCLUSIONS AND SUGGESTIONS}

Based on the results of the study, the Jatropha fresh leaves water extract serves as a stimulant at low concentration and inhibit at high concentrations on the growth of Bok Choy. The optimum concentration to serve as a stimulant is $15 \% \mathrm{v} / \mathrm{v}$. The writers suggest the future researchers research the effect of Jatropha fresh leaves water extract on the growth of other plants. It is expected that this research can be used as a reference for further research.

\section{REFERENCES}

barokah, R., Sumarsono, S., \& Darmawati, A. (2017). Respon Pertumbuhan Dan Produksi Tanaman Sawi Pakcoy (Brassica Chinensis L.) Akibat Pemberian Berbagai Jenis Pupuk Kandang. Doctoral Dissertation, Fakultas Peternakan Dan Pertanian Undip.

Efriyadi, O. (2018). Pengaruh Perbedaan Jenis Media Tanam Hidroponik TERHADAP Pertumbuhan Pakcoy (Brassica RAPA) DAN Kangkung (Ipomoea AQUATIC). Proceeding OF The Urecol, 675-681.

Firmansyah, F., Onngo, T. M., \& Akyas, A. M. (2009). Pengaruh Umur Pindah Tanam Bibit Dan Populasi Tanaman Terhadap Hasil Dan Kualitas Sayuran Pakcoy (Brassica Campestris L., Chinensis Group) Yang Ditanam Dalam Naungan Kasa DI Dataran Medium. Agrikultura, 20(3).

Harahap, F. S., \& Sari, P. M. (2019). Growth And Production Response of Plant Pakcoy (Brassica Rapa L) On Use Of Nasa Light Organic Fertilizer. Jurnal Pertanian Tropik, 6(2), 222-226.

Ir Sukaria Sinulingga, M., \& Tambunan, I. M. M. (T.T.). Analisis Potensi Dan Peluang Ekonomi Biodiesel Dari Minyak Jarak Pagar (Jatropha Curcas L) Sebagai Bahan Bakar Alternatif.

Kasmiyati, S., Kristiani, E. B. E., \& Herawati, M. M. (2018). Pertumbuhan Dan 
Akumulasi Logam Krom Pada Anggota Brassicaceae Yang Ditumbuhkan Pada Media Limbahsludgetekstil. Prosiding Seminar Nasional Pendidikan Biologi, 1, 491-499.

Kojong, V. C. O., Sangi, M. S., \& Pontoh, J. (2013). Uji Kualitas Minyak Biji Adas (Foeniculum Vulgare) Yang Diperoleh Dengan Metode Soxhletasi. Jurnal Mipa, 2(2), 124127.

Muthmainnah, S. R., Ibrahim, N., \& Hardani, R. (2018). Studi Tumbuhan Berkhasiat Obat Pada Suku Kaili Da'a Kecamatan Kinovaro Kabupaten Sigi Sulawesi Tengah. Biocelebes, 12(2).

Perwitasari, B., Tripatmasari, M., \& Wasonowati, C. (2012). Pengaruh Media Tanam Dan Nutrisi Terhadap Pertumbuhan Dan Hasil Tanaman Pakchoi (Brassica Juncea L.) Dengan Sistem Hidroponik. Agrovigor: Jurnal Agroekoteknologi, 5(1), 14-25.

Prabowo, P. (2019). Pengembangan Perangkat Pembelajaran Berbasis Data Euphorbiaceae Hutan Taman Eden 100. Best Journal (Biology Education, Sains AND Technology), 2(2), 24-31.

Rejila, S., \& Vijayakumar, N. (2011). Allelopathic Effect of Jatropha Curcas On Selected Intercropping Plants (Green Chilli And Sesame). Journal OF Phytology.

Risyad, A., Permadani, R. L., \& Siswarni, M. Z. (2016). Ekstraksi Minyak Dari Biji Alpukat (Persea Americana Mill) Menggunakan Pelarut N-Heptana. Jurnal Teknik Kimia Usu, 5(1), 34-39.

Sanderson, K., Bariccatti, R. A., Primieri, C., Viana, O. H., Viecelli, C. A., \& Junior, H.
G. B. (2013). Allelopathic Influence Of The Aqueous Extract Of Jatropha On Lettuce (Lactuca Sativa Var. Grand Rapids) GERMINATION AND DEVELOPMENT. Journal OF Food, Agriculture AND Environment, 11(1), 641-643.

Sarimole, E., Martosupono, M., Semangun, H., \& Mangimbulude, J. C. (2014). Manfaat Jarak Pagar (Jatropha Curcas) Sebagai Obat Tradisional. Prosiding Seminar Nasional Raja Ampat, 9-12.

Setyaningsih, D., Nurmilah, O. Y., \& Windarwati, S. (2013). Kajian Aktivitas Antioksidan DAN Antimikroba Ekstrak Biji, Kulit Buah, Batang DAN Daun Tanaman Jarak Pagar (Jatropha CURCAS L.). Jurnal Teknologi Pangan, 4(2).

Siadi, K. (2012). Ekstrak Bungkil Biji Jarak Pagar (Jatropha Curcas) Sebagai Biopestisida Yang Efektif Dengan Penambahan Larutan Nacl. Jurnal Mipa, 35(1).

Sudaryono, S. (2010). Pengaruh Pupuk Hayati Dan Tanaman Jarak Pagar (Jatropha Curcas L.) TERHADAP Penyerapan Logam Berat Tembaga (Cu) Dan Timbal (Pb) Pada Lahan Berpasir. Jurnal Teknologi Lingkungan Bppt, 11(2), 271-281.

Tiya, A., Suaria, I. N., \& Andriani, A. A. S. P. R. (2019). Pemberian Dosis Biourine Sapi DAN Media Tanam Pada Beberapa Variabel Pertumbuhan DAN Hasil Ekonomis Tanaman Pakcoy (Brassica CHINENSIS L.). Gema Agro, 24(1), 17-21.

Ulung, G., \& Studi, P. (2014). Sehat Alami DENGAN Herbal: 250 Tanaman Berkhasiat Obat (Vol. 1). Gramedia Pustaka Utama. 
Wenno, S. J., \& Sinay, H. (2019). (2019). Kadar Klorofil Daun Pakcoy (Brassica Chinensis L.) Setelah Perlakuan Pupuk Kandang Dan Ampas Tahu Sebagai Bahan Ajar Mata Kuliah Fisiologi Tumbuhan. BIOPENDIX. Jurnal Biologi,
Pendidikan Dan Terapan, 5(2), 130139.

Wiryono, W., \& Nurliana, S. (2019). Dominansi Jenis-Jenis Tanaman Sayur Introduksi di Pasar Sayuran Kota Bengkulu. Life Science, 8(2), 181-191. 